\title{
Jumlah Koloni Bakteri Asam Laktat pada Rongga Mulut yang Sehat
}

\author{
Rheta Elkhaira1, Nila Kasuma², Andani Eka Putra ${ }^{3}$
}

\begin{abstract}
Abstrak
Salah satu flora normal yang terdapat di dalam rongga mulut adalah Bakteri Asam Laktat (BAL). Kemampuan BAL antara lain menghasilkan antimikroba, mengatur respons imun host dan menghalangi pertumbuhan bakteri patogen. Keberadaan BAL di rongga mulut sangat penting untuk menjaga kesehatan oral dan mencegah terjadinya penyakit periodontal. Hal ini mendorong perlunya penelitian mengenai jumlah koloni BAL di dalam rongga mulut yang sehat sehingga dapat dijadikan sebagai alternatif terapi penyakit periodontal. Tujuan: Mengidentifikasi jumlah koloni BAL pada rongga mulut yang sehat. Metode: Penelitian ini merupakan studi observasional dengan rancangan crosssectional. Subyek penelitian terdiri dari 49 orang dengan gusi yang sehat. Subyek diminta untuk berkumur dengan akuades steril kemudian akuades hasil berkumur ditampung untuk selanjutnya dikultur di media MRS. Setelah diinkubasi selama 48 jam dilakukan penghitungan jumlah koloni bakteri asam laktat yang tumbuh pada media MRS. Hasil: Rerata jumlah koloni BAL kelompok sehat 7,8 x 104 $\pm 9,4 \times 10^{4} \mathrm{CFU} / \mathrm{ml}$. Bakteri yang tumbuh pada media MRS pada penelitian ini semuanya berbentuk bundar, umumnya tepian rata, berwarna putih, mukoid, berukuran kecil dengan elevasi cembung. Beberapa bakteri berwarna krem atau putih keruh, berukuran sedang, tidak mukoid, tepian tidak rata dan elevasi seperti tombol. Simpulan: BAL merupakan flora normal yang keberadaannya penting untuk menjaga rongga mulut yang sehat.
\end{abstract}

Kata kunci: BAL, jumlah koloni, kesehatan rongga mulut

\section{Abstract}

Lactic Acid Bacteria ( $L A B)$ is one of the floras that exists inside the oral cavity. $L A B$ are capable of producing antimicrobial compounds to control the immune response of the host, thus preventing the growth of pathogenic bacteria. The existence of $L A B$ is essential to maintain the health of the oral cavity and to prevent any type of periodontal disease. This leads to the importance of research on the amount of $L A B$ in the healthy oral cavity, which may provide an alternative therapy for periodontal diseases. Objectives: To identifed the number of $L A B$ colonies in a healthy oral cavity. Methods:This was an observational analytic with a cross-sectional design. The subject of the research consisted of 49 patients with healthy gingiva. Subjects were asked to gargle sterile aqua dest, then gargled aqua dest samples were cultured in MRS agar media. Cultured samples were incubated under $37^{\circ} \mathrm{C}$ temperature then the number of bacterial colonies formed were counted after 48-hour. Results: The average amount of LAB colonies of the healthy mouth was $7.8 \times 10^{4} \pm 9.4 \times 10^{4}$. The bacterial colonies grown in MRS agar media of this experiment, all have circular form, entire margin, white color, mucoid, small in size, and convex elevation. Several colonies have cream or opaque white color, medium in size, no mucoid, and undulate margin, and umbonate elevation. Conclusion: $L A B$ is normal floras to keep healthy mouth.

Keywords: $L A B$, colony amount, healthy mouth

Affiliasi penulis: 1. Rumah Sakit Gigi Mulut Baiturrahmah Padang, 2. Fakultas Kedokteran Gigi Universitas Andalas Padang, 3. Bagian Mikrobiologi Fakultas Kedokteran Universitas Andalas Padang
Korespondensi: Andani Eka Putra, Rheta Elkhaira

Email:andani1508@med.unand.ac.id rhetaelkhaira@fkg.unbrah.ac.id Telp: 081226954302,081328834631 


\section{PENDAHULUAN}

Kesehatan gigi dan mulut dapat mempengaruhi kualitas hidup karena merupakan bagian yang terintegrasi dengan kesehatan tubuh lainnya secara sistemik. ${ }^{1}$ Profil kesehatan Indonesia tahun 2011 memperlihatkan penyakit jaringan pulpa dan periapikal termasuk sepuluh penyakit terbanyak di Indonesia. Prevalensi karies dan penyakit periodontal yang tinggi di masyarakat menimbulkan dampak yang besar. Rasa sakit akibat karies dan penyakit periodontal dapat menyebabkan keterbatasan fisik dan ketidaknyamanan psikis sehingga menimbulkan gangguan fungsi yang akhirnya menyebabkan berkurangnya kualitas hidup individu. ${ }^{2}$

Situasi kesehatan gigi dan mulut di Indonesia menurut data Riskesdas tahun 2013 memperlihatkan peningkatan persentase penduduk yang mempunyai masalah kesehatan gigi dan mulut dari tahun 2007 yaitu dari 23,2\% menjadi 25,9\%. Persentase penduduk yang mempunyai masalah kesehatan gigi dan mulut dan melakukan perawatan medis untuk mengatasinya juga mengalami peningkatan yaitu dari $29,7 \%$ pada tahun 2007 menjadi $31,1 \%$ pada tahun 2013. Penduduk yang mengalami masalah kesehatan gigi dan mulut pada tahun 2013 mayoritas terjadi pada usia produktif yaitu 35-44 tahun dan 45-54 tahun. ${ }^{1}$ Profil Kesehatan Kota Padang tahun 2013 menunjukkan penyakit gusi dan periodontal termasuk sepuluh penyakit terbanyak di Kota Padang. ${ }^{3}$

Penyakit periodontal berhubungan dengan kesehatan mayarakat karena terjadi pada semua kelompok usia yaitu anak-anak, remaja, dewasa serta lansia ${ }^{4}$. Acuan Global Goals for Oral Health 2020 dibuat oleh WHO pada tahun 2003 karena menyadari pentingnya kesehatan gigi dan mulut. Tujuan acuan Global Goals for Oral Health 2020 adalah meminimalkan pengaruh dari penyakit mulut dan kraniofasial dengan menekankan pada upaya promotif dan mengurangi dampak penyakit sistemik yang bermanifestasi di rongga mulut melalui upaya diagnosa dini, pencegahan dan manajemen yang efektif untuk penyakit sistemik. ${ }^{2}$

Hasil penelitian menunjukkan flora normal berperan penting untuk menjaga homeostatis rongga mulut. ${ }^{5}$ Salah satu flora normal dalam rongga mulut adalah (Bakteri Asam Laktat) BAL yang mempunyai kemampuan untuk menghambat pertumbuhan bakteri patogen sehingga diharapkan dapat memberikan dampak terhadap kesehatan rongga mulut. ${ }^{6}$ Karakteristik BAL adalah menghasilkan asam laktat sebagai produk utamanya karena mempunyai enzim lakto dehidrogenase yang dapat menfermentasi laktosa. ${ }^{7}$ Mikroba dari golongan BAL merupakan probiotik karena mempunyai kemampuan untuk mempertahankan kesehatan dan meningkatkan kesehatan host. ${ }^{8}$ Bakteriosin yang dihasilkan oleh BAL mempunyai efek antimikroba terhadap bakteri patogen sehingga dapat dijadikan alternatif terapi suatu penyakit. $^{9}$

Pencegahan penyakit periodontitis oleh BAL terjadi karena mempunyai kemampuan untuk mengatur respons imun host dan menghalangi perumbuhan bakteri patogen penyebab periodontitis. ${ }^{10}$ Salah satu BAL di rongga mulut adalah Lactobacillus reuteri yang secara in vitro dapat menghambat pertumbuhan bakteri patogen penyebab penyakit gigi dan mulut yaitu Streptococcus mutans, Streptococcus gordinii, Tanerella forsythia, Actynomices naeslundii. ${ }^{11}$ Berdasarkan hal diatas, maka penelitian ini bertujuan untuk mengidentifikasi jumlah koloni BAL pada rongga mulut yang sehat.

\section{METODE}

Penelitian ini merupakan studi analitik observasional dengan rancangan penelitian cross sectional. Subyek penelitian terdiri dari 49 subyek dengan gingiva sehat. Pemilihan subjek penelitian dilakukan dengan cara consecutive sampling yaitu berdasarkan urutan datang pasien yang berobat ke RSGM Baiturrahmah. Subyek sehat adalah pasien yang tidak mempunyai kerusakan jaringan periodontal dengan kedalaman sulkus gingiva 2-3 mm. Kriteria inklusi untuk subyek penelitian adalah pasien laki-laki dan perempuan, usia minimal 18 tahun dan bersedia ikut penelitian. Kriteria eksklusi sebagai subyek penelitian adalah merokok, menderita penyakit sistemik seperti diabetes mellitus, HIV, hipertensi, hamil, mengonsumsi antibiotik dan antiinflamasi selama tiga bulan terakhir. 
Informed consent dan informasi penelitian diberikan kepada subyek yang memenuhi kriteria, kemudian subyek diminta untuk berkumur dengan akuades steril $15 \mathrm{ml}$. Subyek diminta berkumur dengan cara menggerakkan semua akuades steril pada seluruh area di dalam mulut meliputi bagian depan gigi, belakang gigi, bawah lidah dan langit-langit mulut selama 30 detik. Akuades hasil berkumur ditampung dalam pot kemudian dikultur pada media MRS. Setelah diinkubasi selama 48 jam dengan suhu $37^{\circ} \mathrm{C}$, dilakukan penghitungan jumlah koloni BAL yang tumbuh pada cawan petri.

HASIL

Tabel 1. Karakteristik subyek penelitian

\begin{tabular}{lrr}
\hline Karakteristik & Frekuensi & $\%$ \\
\hline Jenis kelamin & 7 & \\
Laki-laki & 42 & 85 \\
Perempuan & & \\
Umur & 3 & 6 \\
21 & 31 & 64 \\
22 & 3 & 6 \\
23 & 8 & 16 \\
24 & 3 & 6 \\
25 & 0 & 0 \\
26 & 1 & 2 \\
27 & & \\
\hline
\end{tabular}

Tabel 1 menunjukkan mayoritas subyek penlitian adalah perempuan. Umur termuda pada penlitian ini adalah 21 tahun, umur tertua adalah 27 tahun dan mayoritas subyek penelitian berumur 22 tahun. Hasil penelitian menunjukkan rerata jumlah koloni BAL pada rongga mulut yang sehat $7,8 \times 10^{4} \pm 9,4 \times 10^{4} \mathrm{CFU} / \mathrm{ml}$.

Bakteri yang tumbuh pada media MRS pada penelitian ini semuanya berbentuk bundar, umumnya tepian rata, berwarna putih, mukoid, berukuran kecil dengan elevasi cembung. Beberapa bakteri berwarna krem atau putih keruh, berukuran sedang, tidak mukoid, tepian tidak rata dan elevasi seperti tombol.

\section{PEMBAHASAN}

Subyek wanita pada kelompok sehat lebih banyak daripada laki-laki, hal ini disebabkan karena wanita pada umumnya lebih menjaga kesehatan rongga mulut dibandingkan lak-laki. Wanita mempunyai kebiasaan untuk lebih menjaga kesehatan gigi dan mulut dibandingkan laki-laki. ${ }^{12}$ Penelitian menunjukkan bahwa walaupun laki-laki dan wanita mempunyai pengetahuan yang sama mengenai kesehatan rongga mulut, tetapi wanita lebih menerapkan tindakan menjaga kesehatan rongga mulut dibandingkan dengan laki-laki dalam kehidupan sehari-hari. ${ }^{13}$

Hasil penelitian menunjukkan rerata jumlah koloni BAL pada rongga mulut yang sehat 7,8 $\times 10^{4} \pm$ 9,4 $\times 10^{4} \mathrm{CFU} / \mathrm{ml}$. Kondisi normal atau sehat merupakan keadaan dinamis yang sangat tergantung pada keseimbangan fungsi organisme dan perubahan lingkungan yang terjadi. ${ }^{14}$ Hasil penelitian menunjukkan mikrobiota oral mempunyai peranan penting untuk menjaga homeostatis rongga mulut. ${ }^{5}$ BAL yang menetap di rongga mulut dapat menjadi probiotik untuk mempertahankan kesehatan rongga mulut. ${ }^{6}$ Probiotik dikategorikan dalam dua kelompok genus yaitu Lactobacillus dan Bifidobacterium. ${ }^{15}$ Keberadaan Lactobacillus berhubungan dengan kesehatan rongga mulut karena Lactobacillus fermentum dan Lactobacillus salivarius dapat menghambat pertumbuhan bakteri patogen penyebab penyakit periodontal. ${ }^{16}$ Bakteri Lactobacillus paracasei, Lactobacillus casei, Lactobacillus salivarius, Lactobacillus plantarum, Lactobacillus rhamnosus dan Lactobacillus fermentum merupakan probiotik yang lebih dapat menghambat pertumbuhan bakteri patogen penyebab penyakit periodontal dibandingkan bakteri probiotik lainnya yang ada di rongga mulut. ${ }^{17}$

Penelitian ini menunjukkan bahwa BAL diperlukan untuk mempertahankan kondisi sehat di rongga mulut. Senyawa antimikroba yang diproduksi oleh BAL dapat menghambat pertumbuhan bakteri patogen penyebab penyakit periodontal sehingga dapat mempertahankan kesehatan rongga mulut ${ }^{6}$. 
Bakteri asam laktat memproduksi senyawa antimikroba antara lain asam organik, bakteriosin, reuterin dan reutericyclin. Asam laktat yang difermentasi BAL dapat penetrasi kedalam sitoplasma suatu mikroba menyebabkan terganggunya metabolisme sehingga terhambatnya perumbuhan bahkan dapat membunuh mikroba tersebut. ${ }^{18}$ Ethanol yang diekstraksi dari Lactobacillus paracasei subsp. paracasei NTU 101 (NTU101FM) dapat digunakan sebagai anti-periodontitis karena menghambat pertumbuhan bakteri patogen penyebab penyakit periodontal. ${ }^{19}$ Bakteri Lactobacillus salivarius dan Lactobacillus gasseri menurunkan ekspresi eksotoksin Aggregatibacter actinomycetemcomitans sehingga dapat menjaga kesehatan rongga mulut. ${ }^{20}$

Bakteri yang tumbuh pada media MRS pada penelitian ini semuanya berbentuk bundar, umumnya tepian rata, berwarna putih, mukoid, berukuran kecil dengan elevasi cembung. Beberapa bakteri berwarna krem atau putih keruh, berukuran sedang, tidak mukoid, tepian tidak rata dan elevasi seperti tombol. Pemeriksaan mikroskopis dengan pewarnaan Gram menujukkan bahwa semua bakteri yang tumbuh merupakan Gram positif berbentuk kokus atau basil.

Hasil ini sama dengan penelitian mengenai karakterisasi isolat bakteri asam laktat yang telah dilakukan sebelumnya. Morfologi koloni Lactobacillus pada saliva berbentuk bulat, cembung, pinggiran rata, berwarna putih atau krem, pemeriksaan mikroskopik Gram positif dan berbentuk batang. ${ }^{21}$ Bakteri asam laktat yang diisolasi dari air susu ibu merupakan Gram positif, berbentuk kokus atau batang, berukuran kecil atau sedang, berwarna krem atau putih dan cembung. ${ }^{22,23}$ Bakteri Lactobacillus yang diisolasi dari feses manusia pada pemeriksaan mikroskopis merupakan Gram positif berbentuk batang atau batang pendek. ${ }^{24}$

\section{SIMPULAN}

Ditemukan jumlah koloni BAL pada rongga mulut yang sehat sebesar $7,8 \times 10^{4} \pm 9,4 \times 10^{4}$ CFU/ml.

\section{SARAN}

Perlu dilakukan penelitian lebih lanjut untuk mengetahui jenis BAL yang berperan dalam menjaga kesehatan rongga mulut.

\section{UCAPAN TERIMA KASIH}

Terima kasih kepada Kepala beserta staf Laboratorium Mikrobiologi Fakultas Kedokteran Universitas Andalas dan Direktur beserta karyawan Rumah Sakit Gigi dan Mulut Baiturrahmah.

\section{DAFTAR PUSTAKA}

1. Kementerian Kesehatan RI (Kemenkes RI). Situasi kesehatan gigi dan mulut. Jakarta: Kemenkes RI; 2014. hlm. 1-3.

2. Kemenkes RI. Rencana program pelayanan kesehatan gigi dan mulut. Jakarta: Kemenkes RI; 2012. hlm. 2,3,5.

3. Dinkes Padang. Profil kesehatan kota Padang. Padang: Dinkes Padang; 2014. hlm.28.

4. Nazir MA. Prevalence of periodontal disease, its asociation with systemic diseases and prevention. International Journal of Health Science. 2017;1(2): 72-80.

5. Ling Z, Kong J, Jia P, Wei C, Wang Y, Pan Z, et al. Analysis of oral microbiota in children with dental caries by PCR-DGGE and barcoded pyrosequencing. Microb Ecol. 2010; 60:677-90.

6. Snel J, Marco ML, Kingma F, Noordman WM, Rademaker J, Kleerebezem M. Competitive selection of lactic acid bacteria that persist in the human oral cavity. Applied and Environmental Microbiology. 2011; 77(23): 8445-50.

7. Feldman-Salit $F$, Hering $S$, Messiha HL, Veith $N$, Cojocaru V, Sieg A, et al. Regulation of the activity of lactate dehydrogenases from four lactic acid bacteria. The Journal of Biological Chemistry. 2013; 288(29): 21295-306.

8. Sari DS, Meilawaty Z, Amin MN. The role of probiotic on alveolar bone resorption. Dental Journal (Majalah Kedokteran Gigi). 2011;44(3): 117-21. 
9. Yusuf MA, Hamid THATA. Lactic acid bacteria: Bacteriocin producer: A mini review. IOSR Journal of Pharmacy. 2013; 3(4): 44-50.

10. Shetty D, Hedge S, Sharath KS, D'souza S. Probiotics and periodontal health. International Journal of Preventive and Clinical Dental Research. 2016; 3(2):120-3.

11. Baca-Castanon ML, Garza-Ramos MAD, AlcazarPizana AG, Grondin Y, Coronado-Mendoza A, Sanchez-Najera RI, et al. Antimicrobial effect of Lactobacillus reuteri on cariogenic bacteria Streptococcus gordonii, Streptococcus mutans, and periodontal diseases Actinomyces naeslundii and Tannerella Forsythia. Probiotics \& Antimicro Prot. 2014:1-8

12. Hamasha AA, Alshehri A, Alshubaiki A, Alssafi F, Alamam H, Alshunaiber R. Gender-specific oral health beliefs and behaviors among adult patients attending King Abdulaziz Medical City in Riyadh. Saudi Dental Journal. 2018;30: 226-31.

13. Mamai-Homata E, Koletsi-Kounari H, Margaritis V. Gender differences in oral health status and behavior of Greek dental students: A meta-analysis of 1981, 2000, and 2010 data. J Int Soc Prev Community Dent. 2016; 6(1):60-8.

14. Reddi S. Essentials of clinical periodontology and periodontic. Edisi ke-3. New Delhi: Jaypee Brothers Medical Publishers; 2011.hlm.82,117-9, 147, 221.

15. Mathew RA, Sankari. Probiotics and periodontal health. IOSR Journal of Dental and Medical Sciences. 2014; 13(8): 37-40.

16. Chen LJ, Tsai HT, Chen WJ, Hsieh CY, Wang PC, Chen CS, et al. In vitro antagonistic growth effects of Lactobacillus fermentum and Lactobacillus salivarius and their fermentative broth on periodontal pathogens, Brazilian Journal of Microbiology, 2012;1376-84.

17. Teanpaisan R, Piwat S, Dahlen G. Inhibitory effect of oral Lactobacillus against oral pathogens, Letters in Applied Microbiology. 2011;53:452-9.

18. Nes IF, Kjos M, Diep DB. Antimicrobial Components of Lactic Acid Bacteria. Dalam: Salminen S, Wright AV, Lahtinen S, Ouwehand A, editor (penyunting). Lactic Acid Bacteria: Microbiological and Functional Aspects. Edisi ke-4. CRC Press: New York; 2012.hlm. 286-8.

19. Liu TH, Tsai TY, Pan TM. The anti-periodontitis effects of ethanol extract prepared using Lactobacillus paracasei subsp. paracasei NTU 101. Nutrients. 2018;10(472):1-13.

20. Nissen L, Sgorbati B, Biavati B, Belibasakis GN. Lactobacillus salivarius and L. gasseri downregulate Aggregatibacter actinomycetemcomitans exotoxins expression. Annals of Microbiology. 2014;64(2):611-7.

21. Ahirwar SS, Gupta MK, Gupta G, Singh V. Screening, isolation and identification of lactobacillus species from dental caries of children. International Journal of Current Microbiology and Applied Sciences. 2018; 6(1):497-503.

22. Bhatt VD, Vaidya YH, Kunjadia PD, Kunjadia AP, Patel R. Isolation and charecterization of probiotic from human milk. International Journal of Pharmaceutical Science and Health Care. 2012; 2(3):62-70.

23. Diba FS, Hossain KM, Azim MA, Hoque MM. Isolation, characterization and determination of antimicrobial properties of lactic acid bacteria from human milk. Jordan Journal of Biological Sciences. 2013; 6(2):111- 6 .

24. Taweechotipatr M, lyer C, Spinler JK, Versalovic, J, Tumwasorn S. Lactobacillus saerimneri and Lactobacillus ruminis: novel human-derived probiotic strains with immune modulatory activities. Federation of European Microbiological Societies Microbiol Lett. 2009; 293: 65-72. 